\title{
FASILITAS BELAJAR DAN MANAJEMEN KELAS SEBAGAI DETERMINAN TERHADAP PRESTASI BELAJAR SISWA
}

\author{
LEARNING FACILITIES AND CLASSROOM \\ MANAGEMENT AS A DETERMINANT OF THE STUDENT \\ LEARNING ACHIEVEMENT
}

Citra Anggraini, Nani Imaniyati

Email: citra.anggraini95@ student.upi.edu; naniimaniyati@upi.edu

\begin{abstract}
ABSTRAK
Tulisan ini mengkaji secara khusus tentang fasilitas belajar dan manajemen kelas sebagai faktor yang diduga mempengaruhi prestasi belajar siswa. Regresi ganda dan korelasi product moment merupakan teknik analisis data yang digunakan untuk mengetahui kontribusi setiap variabel. Berdasarkan hasil analisis, data dikumpulkan melalui metode survey dengan menggunakan angket jawaban tertutup terhadap 78 siswa Sekolah Menengah Kejuruan di Cimahi sebagai responden. Hasil analisis menunjukkan fasilitas belajar dan manajemen kelas berkorelasi sedang terhadap prestasi belajar secara parsial, namun hasil analisis secara simultan menunjukkan korelasi yang kuat. Dari hasil penelitian ini dapat memberikan Implikasi bagi pihak sekolah maupun guru sebagai salah satu acuan untuk meningkatkan prestasi belajar siswa yang optimal.
\end{abstract}

Kata Kunci: fasilitas belajar, manajemen kelas, prestasi belajar.

\begin{abstract}
This article will focus specifically on learning facilities and classroom management as a factor that allegedly influenced the achievement of learning. Multiple regression and product moment correlation is a data analysis technique used to determine the contribution of each variable. Based on the analysis, the data were collected through a survey method by using closed questionnaire to78 students of Vocational High School in Cimahi as respondents. The analysis showed learning facilities and classroom management is being correlated to the partially learning achievement. From this result, it can give an implication for the school and teacher as an option to improve student achievement optimal.
\end{abstract}

Keywords: learning facilities, classroom management, learning achievement 


\section{PENDAHULUAN}

Salah satu cara untuk mencapai tujuan pendidikan yaitu dengan belajar, belajar merupakan proses dari yang awalnya tidak tahu menjadi tahu yang tidak bisa menjadi bisa. Pada proses belajar mengajar pasti adanya keterlibatan guru sebagai pengajar dan penilai. Dari hasil belajar mengajar inilah akan terciptanya prestasi belajar siswa. Dimana prestasi belajar siswa ini adalah sebagai tolak ukur keberhasilan yang dicapai oleh peserta didik. Prestasi belajar merupakan titik tolak dan indikator keberhasilan siswa dan sekolah selama proses pembelajaran berlangsung. Dengan adanya prestasi belajar ini sekolah dapat mengetahui seberapa besar perkembangan perserta didik baik dari segi aspek kognitif, apektif, maupun psikomotor siswa-siswi selama di sekolah.

Prestasi belajar yang belum optimal menjadi isu yang menarik untuk dikaji. Dilihat dari prestasi belajar siswa di salah satu Sekolah Menengah Kejuruan di Cimahi tercermin pada nilai ujian akhir semester siswa yang masih belum mencapai KKM yaitu 75 pada tahun 2016-2017. Presentase siswa yang belum mencapai KKM sebesar 69\% dengan nilai rata-rata 69,81. Pertanyaan yang muncul mengapa prestasi belajar siswa belum optimal? Untuk itu perlu dicari faktor-faktor yang diduga berpengaruh terhadap prestasi belajar siswa yang belum optimal. Faktor yang turut memberikan pengaruh terhadap prestasi belajar siswa yaitu faktor luar dan faktor dalam. Faktor luar instrumental yang terdiri dari: kurikulum atau bahan pelajaran, guru atau pengajar, sarana dan fasilitas, administrasi atau manajemen. Fokus penelitian ini mengenai fasilitas belajar dan manajemen kelas. (Ngalim Purwanto, 2010).

Fasilitas penuh dan sesak mengakibatkan buruknya kualitas udara di dalam ruangan, kurang terjaganya bangunan tempat perkualiahan dan perpustakaan rentan terhadap bahaya cuaca yang buruk. Sumber belajar mengajar yang tidak memadai cenderung berdampak negatif terhadap prestasi belajar siswa. (Udoto, 2011). Dua unsur bangunan individu yang paling penting ditemukan mempengaruhi prestasi belajar siswa adalah kontrol suhu dan kualitas udara. (Earthman dalam Tschannen-moran et al, 2009). Kualitas pendidikan sangat tergantung pada kualitas manajemen kelas. (Saritas dalam Behcet Oral, 2012). Sebenarnya, paling banyak studi yang berkaitan dengan efektivitas guru, ditekankan bahwa kemampuan manajemen kelas seorang guru merupakan faktor utama yang menentukan pengajaran sukses. (Celep dalam Behcet Oral, 2002). Dengan demikian dapat dikatakan bahwa kemampuan guru dalam memanajemen kelas perlu diperhatikan karena akan sangat berdampak terhadap prestasi belajar siswa. Selanjutnya secara khusus kajian ini akan mempertanyakan bagaimana pengaruh fasilitas belajar dan manajemen kelas terhadap prestasi belajar siswa?

\section{TINJAUAN PUSTAKA}

\section{Fasilitas Belajar}

Segala sesuatu yang berkaitan secara langsung dengan peserta didik dan mendukung kelancaran serta keberhasilan proses belajar peserta didik yang meliputi media pembelajaran, alat-alat pelajaran, perlengkapan sekolah dan lain-lain. (Wina Sanjaya 2009). Fasilitas belajar adalah semua yang diperlukan dalam proses belajar mengajar baik bergerak maupun tidak bergerak agar tujuan pendidikan dapat berjalan lancar, teratur, efektif, dan efisien. (Muhroji dkk, 2004). Fasilitas belajar merupakan sarana dan prasarana pembelajaran. Prasarana meliputi gedung sekolah, ruang belajar, lapangan olahraga, ruang ibadah, ruang kesenian dan peralatan olah raga. Sarana pembelajaran meliputi buku pelajaran, buku bacaan, alat dan fasilitas laboraturium sekolah dan berbagai media 
pembelajaran yang lain. (Dimyati dan Mudjiono, 2009). Prasarana dan Sarana merupakan faktor yang turut memberikan perngaruh terhadap hasil belajar siswa. (Aunurrahman, 2012)

Fasilitas fisik adalah sumber daya penting yang diperlukan untuk standar pemeliharaan yang efektif di kelas atau sekolah. Fasilitas ini meliputi bangunan, furniture, peralatan, laboratorium, bengkel dan lainnya yang membantu memberikan instruksional. Ketika kategori fasilitas sekolah yang disediakan memadai, kegiatan kelas menjadi efektif dan efisien. Fasilitas di kelas atau sekolah yang memadai dapat meningkatkan kenyamanan, keselamatan murid atau siswa dan guru, dengan demikian dapat meningkatkan penampilan mereka pula. (Knezevich dalam Okeke, 2013). Literatur yang ada telah menyarankan bahwa fasilitas pendidikan yang lebih dari sekedar bangunan; mereka termasuk segala sesuatu dalam pembelajaran lingkungan yang mendukung upaya guru untuk memanfaatkan potensi siswa, dengan menyediakan lingkungan belajar yang dapat mendorong pengajaran serta menyediakan kesempatan belajar yang aman, sehat, nyaman, dan hemat biaya lingkungan. Namun, pertumbuhan badan penelitian telah mengaitkan prestasi dan perilaku siswa dengan ketersediaan fasilitas pendidikan di sekolah. Fasilitas ini termasuk situs, peralatan fisik, ruang rekreasi dan buku teks yang digunakan untuk pencapaian tujuan pendidikan. (School Construction Home, BrooksPilling and Wright, Udosen, n.d. dalam Issue at al., 2015).

Berkaitan dengan kenyamanan manusia fitur bangunan khusus telah terbukti berhubungan dengan prestasi belajar siswa. Ini termasuk usia bangunan, kontrol iklim, kualitas udara dalam ruangan, pencahayaan, kontrol akustik, klasifikasi desain, dan kesan keseluruhan. (Tschannen-moran et al., 2009). Dua unsur bangunan individu yang paling penting ditemukan mempengaruhi prestasi belajar siswa adalah kontrol suhu dan kualitas udara. (Earthman dalam Tschannen-moran et al, 2009). Adapun indikator fasilitas belajar diantaranya yaitu: (1) Penataan gedung sekolah, (2) Keadaan ruang kelas, (3) Keberfungsian perpustakaan, (4) Fasilitas kelas dan laboratorium, (5) Ketersediaan bukubuku pelajaran, (6) Optimalisasi media atau alat bantu. (Aunurrahman, 2012)

\section{Manajemen Kelas}

Manajemen kelas adalah usaha sadar dari pihak guru untuk menata kehidupan kelas dimulai dari perencanaan kurikulum (meliputi : tujuan pembelajaran, bahan pembelajaran, metode mengajar, alat peraga atau media, evaluasi), pengorganisasian proses belajar mengajar (meliputi: absensi atau daftar kehadiran, kepemimpinan, sikap, suara, pembinaan hubungan baik, pemilihan sumber belajar, pemanfaatan sumber belajar), pengaturan lingkungan (meliputi: ruang belajar, pengaturan tempat duduk, ventilasi dan cahaya, pengaturan penyimpanan barang) untuk memaksimumkan efisiensi, memantau kemajuan siswa dan mengantisifasi masalah-masalah yang akan timbul. (Wijaya, C dan Rusyan, T.A., 2000). Manajemen kelas adalah proses perencanaan, pelaksanaan dan evaluasi yang dilakukan oleh guru, baik individual maupun dengan atau melalui orang lain (semisal dengan sejawat atau siswa sendiri) untuk mengoptimalkan proses pembelajaran. Kata perencanaan disini merujuk pada perencanaan pembelajaran dan unsur-unsur penunjangnya, pelaksanaan bermakna proses pembelajaran, dan evaluasi bermakna evaluasi pembelajaran. Evaluasi disini terdiri dari dua jenis, yaitu evaluasi proses dan evaluasi hasil pembelajaran. (Sudarwan Danim dan Yunan Danim, 2010).

Manajemen kelas adalah salah satu faktor terbesar yang mempengaruhi keberhasilan akademis. Sementara manajemen yang sukses membutuhkan pelatihan, kerja keras, 
perencanaan yang matang, sumber daya yang efektif di sekolah dan dapat melayani berbagai tujuan dalam kelas. (Rossell, 2010). Manajemen kelas mengacu kepada tindakan yang diambil untuk menciptakan dan memelihara lingkungan belajar yang kondusif (mengatur lingkungan fisik, membangun aturan dan prosedur, mempertahankan perhatian siswa saat belajar dan keterlibatannya dalam kegiatan. (Brophy dalam Boer \& Kuijk 2014). Manajemen kelas mengacu pada semua hal yang dilakukan guru untuk mengatur siswa, ruang, waktu dan bahan-bahan untuk memaksimalkan pengajaran yang efektif dan belajar siswa. (Wong \& Wong dalam Chih Lun Hung dan Chih Chieh Fan, 2014). Manajemen mengacu pada tindakan dan strategi yang digunakan guru untuk menetapkan ketertiban di kelas. (Doyle dalam Cabaroglu, 2012). Indikator manajemen kelas diantaranya yaitu (1) bahan Pembelajaran, (2) metode mengajar, (3) alat peraga atau media, (4) evaluasi, (5) kehadiran, (6) kepemimpinan, (7) suara, (8) pembinaan hubungan baik, (9) pengaturan tempat duduk. (Wijaya, C dan Rusyan, T.A., 2000)

\section{Prestasi Belajar}

Prestasi atau hasil belajar (achievement) merupakan realisasi atau pemekaran dari kecakapan-kecakapan potensial atau kapasitas yang dimiliki seseorang. Penugasan hasil belajar oleh seseorang dapat dilihat dari perilakunya, baik perilaku dalam bentuk penguasaan pengetahuan, keterampilan berpikir maupun keterampilan berpikir maupun keterampilan motorik. Di sekolah, hasil belajar ini dapat dilihat dari penguasaan siswa akan mata pelajaran yang ditempuhnya. (Nana Syaodih Sukmadinata, 2003). Prestasi belajar merupakan hasil interaksi dari sebagian faktor yang mempengaruhi proses belajar secara keseluruhan. (Muhibbin Syah, 2008).

Prestasi harus mencerminkan tingkatan-tingkatan siswa sejauh mana siswa telah dapat mencapai tujuan yang ditetapkan setiap bidang studi. Simbol yang digunakan untuk menyatakan nilai, baik huruf maupun angka, hendaknya merupakan gambaran tentang prestasi saja. (Suharsimi Arikunto, 2006). Prestasi belajar adalah penilaian hasil usaha kegiatan belajar yang dinyatakan dalam bentuk simbol, angka, huruf, maupun kalimat yang dapat mencerminkan hasil yang sudah dicapai oleh anak dalam periode tertentu. (Tirtonegoro, 2001).

Kerangka penelitian pada penelitian mengenai fasilitas belajar dan manajemen kelas terhadap prestasi belajar digambarkan sebagai berikut:

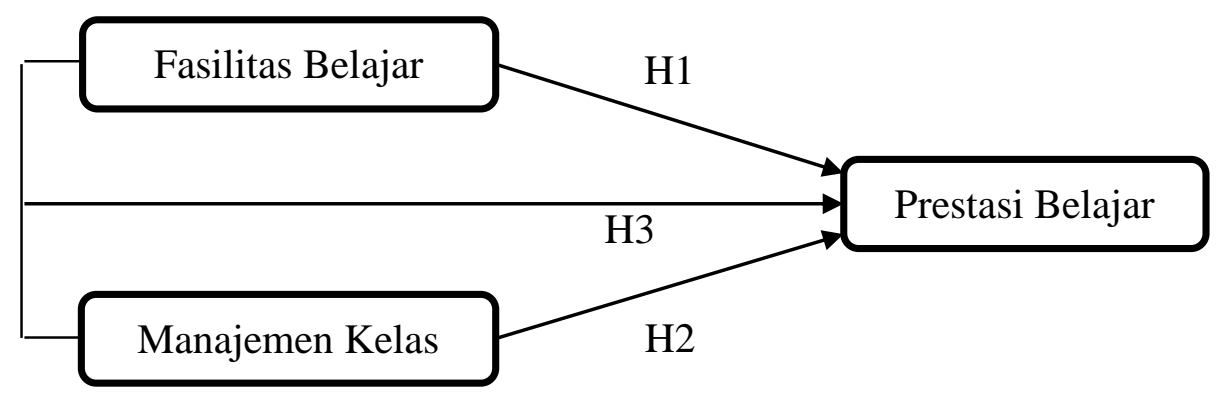

Gambar 1

Research Framework

$\mathrm{H} 1$ = terdapat pengaruh fasilitas belajar terhadap prestasi belajar

$\mathrm{H} 2$ = terdapat pengaruh manajemen kelas terhadap prestasi belajar

$\mathrm{H} 3$ = terdapat pengaruh fasilitas belajar dan manajemen kelas terhadap prestasi belajar 


\section{METODOLOGI}

Penelitian ini dilakukan dengan menggunakan metode survey. Metode ini digunakan untuk mengumpulkan informasi faktual melalui angket. Dalam kajian ini data dikumpulkan dengan menggunakan angket sebagai alat pengumpul data dengan model likert skala 5 mulai dari poin 1 (sangat tidak setuju) samapi poin 5 (sangat setuju). Sumber data pada penelitian ini berjumlah 78 orang terdiri dari dua kelas Administrasi Perkantoran di salah satu sekolah SMK di kota Cimahi.

Instrumen pengumpulan data terdiri dari 3 bagian, bagian pertama adalah angket untuk mengukur fasilitas belajar yang terdiri dari dalam 6 indikator yaitu keadaan gedung sekolah, keadaan ruang kelas, keberfungsian perpustakaan, keadaan fasilitas kelas dan laboratorium, ketersediaan buku-buku pelajaran dan optimalisasi media atau alat bantu. Bagian kedua adalah angket untuk mengukur manajemen kelas yang terdiri dari 9 indikator yaitu bahan pembelajaran, metode mengajar, alat peraga atau media, evaluasi, kehadiran, kepemimpinan, suara, pembinaan hubungan baik dan pengaturan tempat duduk.

Gambaran dari tanggapan responden dalam hal fasilitas belajar, manajemen kelas dan prestasi belajar diperoleh dengan statistik deskriptif menggunakan skor rata-rata tiap bagian. Adapun teknik analisis data yang digunakan untuk menguji hipotesis penelitian adalah korelasi product moment dan regresi ganda.

\section{HASIL PENELITIAN DAN PEMBAHASAN Deskripsi Variabel Penelitian}

Hasil survey fasilitas belajar yang ditujukan kepada siswa kelas XI pada mata pelajaran mengelola peralatan kantor program keahlian Administrasi Perkanotoran menunjukkan bahwa fasilitas belajar pada mata pelajaran tersebut berada pada kategori cukup tinggi. Demikian halnya dengan manajemen kelas dari survey terhadap siswa yang sama diperoleh hasil manajemen kelas ini cukup efektif. Hal ini mengindikasikan bahwa guru harus mampu menciptakan kondisi belajar yang optimal, sehingga proses belajar mengajar dapat berjalan efektif. Sedangkan kondisi prestasi belajar siswa yang dalam hal ini menggunakan nilai ujian akhir semester siswa. Berdasarkan kriteria ketuntasan minimal hasilnya menunjukkan secara rata-rata berada pada rentang kemampuan rendah. Maka secara keseluruhan nilai diperoleh belum mencapai prestasi belajar yang optimal. Hal ini dibuktikan dengan skor rata-rata variabel yang tersaji pada table sebagai berikut:

Tabel 1

Jumlah Skor Rata-rata Variabel

\begin{tabular}{|l|c|c|c|c|}
\hline & $\begin{array}{c}\text { Jumlah } \\
\text { Responden }\end{array}$ & $\begin{array}{c}\text { Variabel } \\
\text { Fasilitas Belajar }\end{array}$ & $\begin{array}{c}\text { Variabel } \\
\text { Manajemen } \\
\text { Kelas }\end{array}$ & $\begin{array}{c}\text { Variabel } \\
\text { Prestasi Belajar }\end{array}$ \\
\cline { 1 - 4 } $\begin{array}{l}\text { Jumlah Skor } \\
\text { Variabel }\end{array}$ & 78 & 3669 & 3621 & 5448 \\
\cline { 1 - 4 } $\begin{array}{l}\text { Rata-rata Skor } \\
\text { Variabel }\end{array}$ & 78 & 46 & 69 \\
\hline
\end{tabular}




\section{H1: Pengaruh Fasilitas Belajar terhadap Prestasi Belajar}

Penelitian pada fasilitas belajar terhadap prestasi belajar bertujuan untuk menjawab hipotesis penelitian 1 yaitu terdapat pengaruh positif dan signifikan fasilitas belajar terhadap prestasi belajar siswa. Kesimpulan diambil setelah melakukan pengujian dengan menggunakan uji $\mathrm{F}$ dan didapatkan hasil $\mathrm{F}_{\text {hitung }}>\mathrm{F}_{\text {tabel }}$ maka hipotesis 1 diterima dan hipotesis $0(\mathrm{H} 0)$ ditolak.

Berdasarkan pengujian perhitungan statistik diperoleh $F_{\text {hitung }}$ sebesar 19,464, sedangkan $\mathrm{F}_{\text {tabel }}$ dengan tingkat kesalahan $\alpha=0,05 \mathrm{dan} \mathrm{dk}$ reg $\mathrm{b} / \mathrm{a}=1$ dan $\mathrm{dk}$ res $=\mathrm{n}-2=76$ sebesar 3,967, artinya $F_{\text {hitung }}>F_{\text {tabel }}$ yaitu 19,464 > 3,967 maka hipotesis 1 diterima. Disimpulkan adanya pengaruh positif dan signifikan fasilitas belajar terhadap prestasi belajar.

Besarnya keterkaitan antar variabel dihitung dengan menggunakan koefesien korelasi. Berdasarkan hasil penelitian koefesien korelasi pada variabel fasilitas belajar terhadap prestasi belajar sebesar 0,4515. Besarnya nilai koefesien korelasi pada rentang 0,400-0,599, jika ditafsirkan pada tabel kriteria koefesien korelasi berada pada tingkat hubungannya sedang.

Diperkuat dengan temuan penelitian (Tschannen-moran et al., 2009) bahwa kualitas fasilitas sekolah dan iklim sekolah memberikan pengaruh sebesar 39\% terhadap prestasi siswa.

\section{H2: Pengaruh Manajemen Kelas terhadap Prestasi Belajar}

Penelitian pada manajemen kelas terhadap prestasi belajar bertujuan untuk menjawab hipotesis penelitian 2 yaitu terdapat pengaruh positif dan signifikan manajemen kelas terhadap prestasi belajar siswa. Kesimpulan diambil setelah melakukan pengujian dengan menggunakan uji $\mathrm{F}$ dan didapatkan hasil $\mathrm{F}_{\text {hitung }}>\mathrm{F}_{\text {tabel }}$ maka hipotesis 2 diterima dan hipotesis $0(\mathrm{H} 0)$ ditolak.

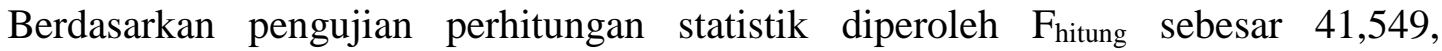
sedangkan $\mathrm{F}_{\text {tabel }}$ dengan tingkat kesalahan $\alpha=0,05 \mathrm{dan} \mathrm{dk}$ reg $\mathrm{b} / \mathrm{a}=1$ dan $\mathrm{dk}$ res $=\mathrm{n}-2=76$ sebesar 3,967, artinya $F_{\text {hitung }}>F_{\text {tabel }}$ yaitu 41,549 > 3,967 maka hipotesis 2 diterima. Disimpulkan adanya pengaruh positif dan signifikan manajemen kelas terhadap prestasi belajar.

Besarnya keterkaitan antar variabel dihitung dengan menggunakan koefesien korelasi. Berdasarkan hasil penelitian koefesien korelasi pada variabel manajemen kelas terhadap prestasi belajar sebesar 0,5945. Besarnya nilai koefesien korelasi pada rentang 0,400-0,599, jika ditafsirkan pada tabel kriteria koefesien korelasi berada pada tingkat hubungannya sedang

Diperkuat dengan temuan penelitian oleh (Chung \& Ackerman 2015) analisiss regresi menunjukkan faktor yang mempengaruhi keseluruhan dari manajemen kelas dengan determinsasi $31,31 \%$.

\section{H3: Pengaruh Fasilitas Belajar dan Manajemen Kelas terhadap Prestasi Belajar}

Teknik analisis data yang digunakan untuk mengetahui pengaruh secara simultan variabel fasilitas belajar dan manajemen kelas terhadap prestasi belajar siswa digunakan regresi ganda (multiple regression). Berdasarkan hasil perhitungan menggunakan regresi ganda diperoleh persamaan regresi $\hat{\mathrm{Y}}=-2,839+0,739\left(\mathrm{X}_{1}\right)+0,817\left(\mathrm{X}_{2}\right)$. Persamaan ini dapat diartikan terdapat hubungan yang positif antara variabel bebas pertama dan variabel 
bebas kedua, keduanya berjalan searah artinya ketika ada peningkatan pada satu variabel maka ada peningkatan pada variabel lainnya begitupun sebaliknya.

Berdasarkan pengujian perhitungan statistik kesimpulan diambil setelah melakukan pengujian dengan menggunakan uji $\mathrm{F}$ dan didapatkan hasil $\mathrm{F}_{\text {hitung }}>\mathrm{F}_{\text {tabel }}$ maka hipotesis 3 diterima dan hipotesis 0 (H0) ditolak.

Hasil penelitian ini diperoleh $F_{\text {hitung }}$ sebesar 52,5240 sedangkan $F_{\text {tabel }}$ dengan tingkat kesalahan $\alpha=0,05$ dan $d b_{1}=\mathrm{k}$, dan $d b_{2}=\mathrm{n}-\mathrm{k}-1$ yaitu $\mathrm{F}_{(0,05 ; 2 ; 76)}=3,1170$, artinya $\mathrm{F}_{\text {hitung }}>$ $\mathrm{F}_{\text {tabel }}$ yaitu 52,5240 > 3,1170. Maka hipotesis 3 diterima. Disimpulkan adanya pengaruh positif dan signifikan fasilitas belajar dan manajemen kelas terhadap prestasi belajar.

Besarnya keterkaitan antara variabel dihitung dengan menggunakan koefesien korelasi secara simultan antara variabel fasilitas belajar, variabel manajemen kelas dan variabel prestasi belajar. diperoleh hasil koefesien korelasi sebesar 0,6295. Besarnya nilai koefesien korelasi pada rentang 0,600-0,799 jika ditafsirkan pada tabel kriteria koefesien korelasi berada pada tingkat hubungannya kuat. Selanjutnya untuk mengetahui besarnya pengaruh dihitung melalui nilai koefesien determinasi diperoleh dengan menghitung kuadrat dari nilai koefesien dikali $100 \%$. Nilai koefesien determinasi untuk variabel fasilitas belajar dan manajemen kelas secara bersama-sama 39,63\% terhadap prestasi belajar. Sisanya $60,37 \%$ dipengaruhi oleh factor lain yang tidak diteliti pada penelitian ini. Disimpulkan secara keseluruhan fasilitas belajar dan manajemen kelas berpengaruh positif dan signifikan terhadap prestasi belajar.

Tabel 2

Rekapitulasi Koefesien Korelasi

\begin{tabular}{|c|l|c|}
\hline No. & \multicolumn{1}{|c|}{ Variabel } & Nilai Koefesien Korelasi \\
\hline 1. & Fasilitas Belajar & 0,4515 \\
\hline 2. & Manajemen Kelas & 0,5945 \\
\hline 3. & Fasilitas belajar dan Manajemen Kelas & 0,6295 \\
\hline
\end{tabular}

Sumber: Hasil pengolahan data

Tabel 3

Analisis Regresi

\begin{tabular}{|c|l|c|c|l|}
\hline No. & \multicolumn{1}{|c|}{ Variabel } & Fhitung & Ftabel & \multicolumn{1}{|c|}{ Kesimpulan } \\
\hline 1. & Fasilitas Belajar & 19,464 & 3,967 & $\begin{array}{l}\text { Terdapat pengaruh positif dan } \\
\text { signifikan fasilitas belajar } \\
\text { terhadap prestasi belajar }\end{array}$ \\
\hline 2. & Manajemen Kelas & 41,549 & 3,967 & $\begin{array}{l}\text { Terdapat pengaruh positif dan } \\
\text { signifikan manajemen kelas } \\
\text { terhadap prestasi belajar }\end{array}$ \\
\hline 3. & $\begin{array}{l}\text { Fasilitas belajar dan } \\
\text { Manajemen Kelas }\end{array}$ & 52,5240 & 3,1170 & $\begin{array}{l}\text { Terdapat pengaruh positif dan } \\
\text { signifikan fasilitas belajar dan } \\
\text { manajemen kelas terhadap } \\
\text { prestasi belajar }\end{array}$ \\
\hline
\end{tabular}

Sumber: Hasil pengolahan data 


\section{KESIMPULAN}

Fasilitas belajar dan manajemen kelas merupakan faktor yang kuat mempengaruhi prestasi belajar siswa. Sebagaimana hasil penelitian menunjukkan bahwa fasilitas belajar dan manajemen kelas baik secara parsial maupun simultan berpengaruh terhadap prestasi belajar. secara parsial terdapat korelasi yang secdang antara fasilitas belajar terhadap prestasi belajar demikian pula dengan manajemen kelas terhadap prestasi belajar yang berkorelasi sedang. Namun korelasi secara simultan antara fasilitas belajar dan manajemen kelas terhadap prestasi belajar siswa memiliki korelasi yang kuat dengan nilai koefesien korelasi yang lebih besar dibandingkan dengan korelasi secara parsial. Dengan demikian untuk meningkatkan prestasi belajar siswa yang optimal perlu peningkatan dari segi fasilitas belajar dan manajemen kelas secara bersama-sama dan berkelanjutan.

\section{DAFTAR PUSTAKA}

Aunurrahman. (2012). Belajar dan Pembelajaran. Bandung: Alfabeta.

Arikunto, Suharsimi. (2006). Dasar-dasar Evaluasi Pendidikan. Jakarta: Bumi aksara.

Behcet Oral, 2012. Student Teachers Classroom Management Anxiety: A Study on Behavior Management and Teaching Management. Journal of Apllied Social Psychology, Vol. 42, No. 12, hal. 2901-2916.

Cabaroglu, N., 2012. Prospective EFL Teachers Perceptions of Prospective EFL Teachers Perceptions of Classroom Management and Misbehaviour. Cukurova University Faculty of Education Journal, Vol. 41, No. 1, hal. 117-132.

Chih Lun Hung dan Chih Chieh Fan, (2014). Perceived classroom management and student learning motivation in social studies of taiwan junior high school students. European journal of research in social sciences. Vol. 2, hal. 3, hal.40-51.

Chung, C. \& Ackerman, D., 2015. Student Reactions to Classroom Management Technology: Learning Styles and Attitudes Toward Moodle. Journal of educational for business, Vol. 90, hal. 217-223.

Danim, S. dan Yunan Danim. (2010). Administrasi Sekolah dan Pengelolaan Kelas. Bandung: Pustaka Setia.

Issue, V., Ntim, C.K. \& Korletey, J.T., (2015). The Impact of Educational Facilities on Teaching and Learning Drawing: What it Means to Visual Arts Education in Ghana. International journal of innovative research and development. Vol. 4, No. 6, hal.1-12.

Korpershoek, H., Harms, T., de Boer, H., van Kuijk, M., \& Doolaard, S. (2014). Effective classroom management strategies and classroom management programs for educational practice. Groningen: RUG/GION.

Mudjiono, Dimyati. (2009). Belajar dan Pembelajaran. Jakarta: Rineka Cipta. 
Muhibbin Syah. (2008). Psikologi Pendidikan dengan Pendekatan Baru. Bandung: Remaja Rosdakarya.

Muhroji, dkk. (2004). Manajemen Pendidikan. Surakarta: Universitas Muhammadiyah Surakarta.

Nana Syaodih SSukamadinata. (2003). Landasan Psikologis Proses Pendidikan. Cetakan Kedua. Bandung: PT Remaja Rosdakarya.

Okeke, F.N., (2013). Management of Facilities in the Classroom. Journal of Emerging Trends in Educational Research and Policy Studies. Vol 4, No. 1, hal.100-104.

Purwanto, Ngalim. (2010). Psikologi Pendidikan. Bandung: PT. Remaja Rosdakarya.

Rossell, C.H., 2010. Encyclopedia of Cross-Cultural School Psychology C. S. ClaussEhlers, ed., Boston. MA: Springer US.

Sanjaya, Wina. (2009). Strategi Pembelajaran Berorientasi Standar Proses Pendidikan. Jakarta: Kencana.

Sutratinah Tirtonegoro. (2001). Penelitian Hasil Belajar Mengajar. Surabaya: Usaha Nasional

Tschannen-moran, C.U.M. et al., 2009. The walls speak: the interplay of quality facilities, school climate, and student achievement. Journal of Educational Administration, Vol. 46 No.1, hal. 55-73.

Udoto, M.N.M.O., 2011. Quality of learning facilities and learning environment Challenges for teaching and learning in Kenya's public universities. Vol. 19, No. 3, hal. 208-223.

Wijaya, C. dan Rusyan, T.A. (2000). Kemampuan Dasar Guru dalam Proses Belajar Mengajar. Bandung: Remaja Rosdakarya. 